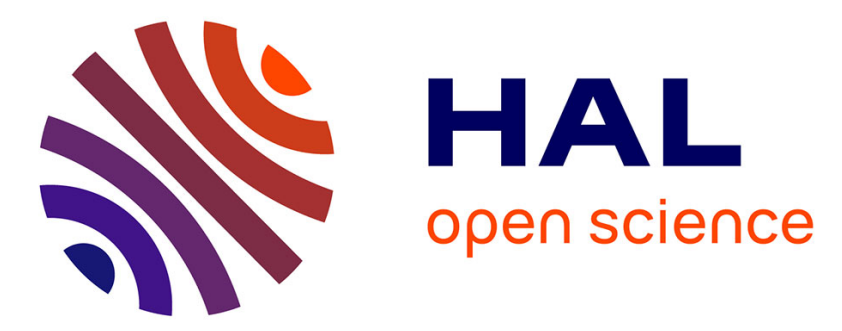

\title{
"We don't want to be governed like this anymore": protest democracy as an expression of a crisis of governmentality in post-revolution Tunisia
} Thierry Desrues, Eric Gobe

\section{- To cite this version:}

Thierry Desrues, Eric Gobe. "We don't want to be governed like this anymore": protest democracy as an expression of a crisis of governmentality in post-revolution Tunisia. British Journal of Middle Eastern Studies, In press, 10.1080/13530194.2021.1996333 . halshs-03502554

\section{HAL Id: halshs-03502554 \\ https://shs.hal.science/halshs-03502554}

Submitted on 25 Dec 2021

HAL is a multi-disciplinary open access archive for the deposit and dissemination of scientific research documents, whether they are published or not. The documents may come from teaching and research institutions in France or abroad, or from public or private research centers.
L'archive ouverte pluridisciplinaire HAL, est destinée au dépôt et à la diffusion de documents scientifiques de niveau recherche, publiés ou non, émanant des établissements d'enseignement et de recherche français ou étrangers, des laboratoires publics ou privés. 


\title{
"We don't want to be governed like this anymore": protest democracy as an expression of a crisis of governmentality in post-revolution Tunisia.
}

\author{
Thierry Desrues, Researcher, IESA-CSIC, Cordoba, Spain. \\ Email: tdesrues@iesa.csic.es (corresponding author) \\ https://orcid.org/0000-0002-7097-405X
}

Eric Gobe, Director of Research at CNRS, IREMAM, Aix-en-Provence.

Email: jbheuman@gmail.com

https://orcid.org/0000-0002-1976-2983

Funding: This paper presents some results of the research project 'Crisis and political representation in North Africa. Institutional arrangements and protests' [grant number: CSO2017-84949-C3-2-P], supported by the Spanish Ministry of Economy, Industry and Competitiveness (MINECO), the Spanish State Research Agency (AEI), and the European Regional Development Fund (ERDF, EU).

\begin{abstract}
This article analyses the political significance of the protests that have arisen in Tunisia since the 'revolution' and the establishment of a parliamentary regime. This is what the protests studied have in common: they belong to neglected regions in the country's hinterland; that they mobilise young local populations; they claim rights over their territories' soil and subsoil resources exploitation; they occupy a strategic location for a relatively long period of time; and they set up democratic mechanisms for these locations' self-management, in the form of 'coordinations'. The description of social logics and the way populations resist, as well as the authoritarian rationality of government action and the inability of elected officials to mediate conflicts, reveal differences between protesters who seek autonomy from state control, while others refer to a rent-centred understanding of the claim. It also shows the emergence of a 'protest democracy', itself an expression of a crisis of 'governmentality'. These two phenomena are symptomatic of a demand for integrating populations and new ways of governing that break with the reeks of past authoritarianism and current representative democracy.
\end{abstract}

Keywords: Protests, representative democracy, authoritarianism, governmentality, Tunisia 


\section{Introduction}

In their analysis of the of 14 January 2011 Tunisian 'revolution', most works have emphasised that protest movements started from the rural areas of the country's central-western region, then spilled over to big cities' segregated neighbourhoods before reaching the urban areas housing the middle-classes. ${ }^{1}$ Consequently, these mobilisations took shape on the 'margins', i.e., in 'economically, socially and/or politically disadvantaged spaces'.2 Even before the fall of Ben Ali's authoritarian regime (1987-2011), they referred to specific integration and recognition demands by the underprivileged, i.e., the Zwaoula (the miserable) and those behind the signs (min oura el blaiek). ${ }^{3}$

Despite the establishment of a parliamentary representative regime in 2014, Tunisia has been experiencing, at more or less regular intervals, protest episodes originating from these margins of the country's interior. They take the form of grievance movements centred on land exploitation and obtaining a right of control over natural resources.

This article examines the political significance of these protests, their social logics, and the inability of the new parliamentary regime's official political sphere to represent the population and mediate conflicts. We argue that these movements, which are part of what the social movements and revolutions sociology calls the 'Contentious politics', are indicative of the emergence of a 'protest democracy', itself an expression of a 'governmentality' crisis as defined by Foucault ${ }^{6}$.

The philosopher Jean-Claude Monod ${ }^{7}$ makes a heuristic use of the concept of governmentality, borrowed from Michel Foucault, ${ }^{8}$ which is useful for understanding the collective actions that have taken place in Tunisia since the revolution. This concept refers to "a set of "reversible" power relations, a form of "conduct of conduct", "techniques and procedures intended to direct men's conduct", the "meeting point between the power technologies and the selftechnologies". " What is important here is the relational aspect of the techniques of power, articulating a history of governmental rationalities and an examination of how the governed resist them. Governmentality thus refers to "an art of governing" and to a given historicalpolitical regime that secretes its own counter-conducts and forms of resistance.

Therefore, a governmentality crunch puts 'in crisis a set of power relations' in a particular temporality where 'something like, we no longer want to govern and/or be governed in this way' is being articulated. ${ }^{10}$ Finally, they "are declined in the plural" and "mark [...] the

\footnotetext{
${ }^{1}$ See Amin Allal, 'Trajectoires révolutionnaires en Tunisie. Processus de radicalisation en Tunisie 2007-2011', RFSP 62, no.5 (2012): 821-841. Mouldi Lahmar M. (ed.), 'al-Thawra al-Tunisiya. al-Qâdih al-Mahalî tahta Mihjar al-'Ulûm al-Insâniyya' [The Tunisian revolution. The local spark under the microscope of the human sciences], Markaz al-arabî li-l-abhâth wa dirasat al-siyasiyât, Beyrouth, 2014. Sami Zemni, 'The Tunisian Revolution: Neoliberalism, Urban Contentious Politics and the Right to the City', International Journal of Urban and Regional Research 41, no. 1 (January 2017): 70-83.

${ }^{2}$ For the concept of the 'margins' in the North African context see Naoual Belakhddar, “'L'éveil du Sud ou quand la contestation vient de la marge. Une analyse du mouvement des chômeurs algériens', Politique africaine 137 (2015): 27-48.

${ }^{3}$ The expression Oura al blaiek means 'behind the official signs' that indicate the presence of administration in a given area. It refers to those who live beyond these signs in areas left behind by state institutions located in urban centres of some importance. By extension, it refers to populations that do not share the urban culture of large cities.

${ }^{4}$ See Charles Tilly and Sydney Tarrow, Contentious Politics (Boulder: Paradigm Publishers, 2006).

${ }^{5}$ Lilian Mathieu, La démocratie protestataire. Mouvements politiques et sociaux en France aujourd'hui (Paris: Les Presses de SciencesPo, 2011).

${ }^{6}$ Michel Foucault, Naissance de la biopolitique. Cours au collège de France, 1978-1979 (Paris : Gallimard, 2004).

${ }^{7}$ Jean-Claude Monod, L'art de ne pas être trop gouverné (Paris: Seuil, 2019).

${ }^{8}$ Foucault, Naissance de la biopolitique.

${ }^{9}$ Monod, L'art de ne pas être trop gouverné, 35.

${ }^{10}$ Ibid., 37-38.
} 
persistent fact that power configurations inevitably give rise to the development of counterconducts'"

We formulate an initial argument according to which the current governmentality crisis in Tunisia is a continuation of the one that led to the 2011 uprising. This governmentality crisis refers to that of a paternalistic authoritarian Tunisian state, which beyond the differences in its successive historical forms - 'socialist' clientelist in the 1960s, 'semi-liberal' clientelist until the mid-1980s, and then oligarchic and 'rentier-mafioso' under Ben Ali's reign ${ }^{11}$ - was undeniably shaken, but not brought down by the 2010-2011 revolution.

In other words, the regime's governmentality crisis that emerged from independence in 1956 corresponded to a political and economic degeneration of an authoritarian, paternalistic and clientelist art of governing, which characterized the modes of domination of Bourguiba and Ben Ali's Tunisia. ${ }^{12}$ The application of neo-liberal economic and financial adjustment measures in the 1980s broke the implicit social contract between the regime, the population and its intermediary bodies, such as the Tunisian General Labor Union (UGTT). This social contract implied allegiance to the rulers in return for subsidized access to basic necessities or employment provided through the public sector. Its breakdown in the 1980s and 2000s triggered large-scale destabilizing social conflicts.

The 1984 popular uprisings under Bourguiba and in the Gafsa mining basin in 2008 under Ben Ali were symptoms of the governmental crisis of state paternalism. The January 1984 bread riots started from the "margins", more precisely from the southern governorates, and spread to Tunis and the Sahel cities. These riots followed the decision taken by the Bourguiba government, under pressure from the International Monetary Fund (IMF), to drastically reduce state subsidies for basic necessities (pasta, semolina and bread). This decision called into question the social contract implicit since independence between the state and the working classes. Also, to curb the uprising, the Bourguiba government was forced to enlist the help of the army and to cancel the planned price increases. ${ }^{13}$

Similar logics were at work in the 2008 Gafsa mining basin uprising. ${ }^{14}$ Until the 1990s, resources redistribution in the mining basin was handled by the Gafsa Phosphate Company (CPG). Indeed, the public company was the in the region's main job provider and the funder of social and cultural schemes. However, the modernization of the company promoted by the World Bank has meant a drop of three-quarters of its workforce between the early 1990s and 2008. As a result, the underprivileged segments of the population felt abandoned by the State. In January 2008, the publication of the lists of successful candidates in a recruitment competition organized by the CPG was seen as a denial of justice by young unemployed people denouncing their exclusion from public employment and the nepotistic nature of recruitment within the CPG. The riots and sit-ins, which lasted from January to June 2008, were carried out by unemployed workers, unemployed graduates and precarious workers led by local trade unionists who were members of the basic union of primary education. The government had to send in the army to put down the uprising in the mining basin. ${ }^{15}$ Subsequently, the government, aware of the danger that a local protest movement could turn into a national uprising, restored the terms of the old social contract by implementing an economic and social intervention plan

\footnotetext{
${ }^{11}$ Aziz Krichen, L'Autre chemin (Tunis : Script Éditions, 2019), 24-30.

${ }^{12}$ Michel Camau, 'Une révolution sans révolution? Une révolution peut en cacher une autre', Revue Tunisienne de Science Politique 6, no1 (2021), 50.

${ }^{13}$ Larbi Chouikha \& Eric Gobe, Histoire de la Tunisie depuis l'indépendance, Paris, La Découverte, 2015, p. 37.

${ }^{14}$ The economy of the Gafsa governorate, located in southeastern Tunisia, is based primarily on its phosphate mines. In the two decades prior to the 2011 revolution in Tunisia, the country was among the world's top five phosphate producers.

${ }^{15}$ Eric Gobe, 'The Gafsa Mining Basin between Riots and a Social Movement: meaning and significance of a protest movement in Ben Ali's Tunisia', Working Paper, IREMAM, April 2021, https://halshs.archivesouvertes.fr/halshs-00557826.
} 
that mainly created social jobs financed by the CPG between 2008 and 2010, in the framework of phosphate sector subsidiaries. ${ }^{16}$ The aim was to prevent a repetition and possible territorial extension of the conflict. In 1984 and 2008, it was the excesses of neo-liberal governmentality, coupled with a nepotistic drift in the latter case, that led the population to rebel. Therefore, those in power would return to the old form of governmentality, which was certainly authoritarian, but nonetheless paternalistic in its promise to guarantee access to basic foodstuffs and an income for the population through public employment.

As for the 2010-2011 revolution, it crystallised as well, to varying degrees, most of the recurrent features of the expression of the governmentality crisis that is currently affecting many societies, as highlighted by Monod ${ }^{17}$ : 'the crisis of governmentality expresses a feeling of abuse, $[\ldots]$ in the sense of an excess in a form of governmentality'; beyond the particular rulers it targets (the "release" of the Tunisian revolution), it "overflows into questioning a mode of government'; it 'often stems from a [...] seemingly minor event [...] out of all proportion to the upheavals that ensue'. It 'takes the form of a multiplication of demands, claims, protests, rather than a fixed programme'. Unlike in 1984 and 2008, the government was unable to step back in time and propose solutions, allowing the crisis to spread rapidly throughout the country.

Our initial assumption does not mean that Tunisia is still the same as it was in 2011, despite the break-up of the country. The latter opened a new political cycle characterised by a liberalisation of the media and political fields that allowed conflicts to be expressed. In 2014, the political field's liberalisation led to the adoption of a constitution establishing a parliamentary-type representative democracy part of the political elites and the upper middle classes aspired to.

However, it did not respond to the aspirations of the subaltern groups in the hinterland and in the urban peripheries. So, we make a second assumption: the popular categories experience representative government as a usurpation of the demos. They perceive the political elites not only as having failed to meet their obligations to them by no longer providing the resources likely to contribute to their betterment, but also as appropriating the State's resources, at the expense of the populations of Tunisia's hinterlands. ${ }^{18}$ In other words, regional segregation is experienced as democratic denial. The demand for the application of the principles of freedom, equality especially, is used by protest movements against an institutional system they feel excluded from. Their actions are aimed at obtaining jobs, preferably public ones, rather than demanding a transformation of social structures. At the same time, the government does not seem capable of creating jobs in the public sector and thus of defusing various conflicts. Since the fall of the old regime, some analysts have approached these conflicts in Gramscian terms as the affirmation of a 'crisis of hegemony' "which will give way to the emergence and development of socio-political behaviour related to what Gramsci identifies as a "wave of materialism', with a focus on strictly economic interest and gain". ${ }^{19}$ The Tunisian economist Baccar Gherib sees in the regional protest movements both the result of the functioning of parliamentary political institutions - unable as they are to accommodate social tensions - and the expression of a local egoism that is a form of 'subversism', i.e., 'a sort of private, unorganized rebellion of a number of groups or individuals against the weakened State, who, however, at the same time, are internalizing their status as subordinates' ${ }^{20}$

\footnotetext{
${ }^{16}$ Béatrice Hibou, 'Le bassin minier de Gafsa en déshérence. Gouverner le mécontentement social en Tunisie', in L'État d'injustice au Maghreb. Maroc et Tunisie, ed. Irene Bono et al. (Paris: Karthala, 2015), 340.

${ }^{17}$ Monod, L'art de ne pas être trop gouverné, 131.

18 About this, see the results of Besma Loukil's survey, 'Inégalités territoriales dans un contexte tunisien postrévolutionnaire' in ed. Melliti I. et Moussa H., Quand les jeunes parlent d'injustice, Expériences, registres et mots en Tunisie, (Paris: L'Harmattan, 2018), 193-225.

19 Baccar Gherib (2020), 'Revolution and transition in Tunisia as crises of hegemony', The Journal of North African Studies, 9. DOI: 10.1080/13629387.2020.1801269.

${ }^{20}$ Some concepts in Gramsci"s thought have recently been mobilized by various authors, notably that of "passive revolution" insofar as it would allow for an account of the paradox of a "revolution with no revolution". However,
} 
However, in the countryside of Tunisia's hinterland, the protest movement against the authoritarian and paternalistic order did not take the form of subversivism: dissent refers to a desire for autonomy and rejection of the plundering of their land by the tutelary state under Bourguiba and by the rentier bourgeoisie under Ben Ali.

Nevertheless, beyond their diversity, the counter-conducts studied in this article are symptoms of the inability of post-2011 political elites to construct an alternative political-economic regime that could meet the protesters' demands for social democracy and replace the governmental arrangements implemented under Bourguiba and Ben Ali. ${ }^{21}$

The first two collective actions we analyze concern two movements of unemployed and unemployed graduates from urban social categories in three segregated regions of the country's hinterland (Kasserine, Tataouine) carrying the same watchwords as during the 2010-2011 uprising (employment, freedom, development, national dignity...).

The first protest movement studied was born in the Kasserine governorate, a region in westcentral Tunisia bordering Algeria and considered, along with Sidi Bouzid, as the cradle of the 2010-2011 revolutionary uprising. Composite from a socio-economic point of view, this governorate, still mostly rural (urbanization rate $43.5 \%$ ) and lacking urban tradition has seen the city of the same name, a merely a small town in the 1950s, enjoying an urban growth linked to its status as the governorate's capital and the installation of a paper industry to enhance the esparto harvest. Kasserine, a mushroom town, has drained the rural exodus from the region, itself a consequence of the impoverishment of the countryside and has become a center of informal activities and unemployment. ${ }^{22}$ The second movement took place in the Tataouine governorate in southern Tunisia, specifically at the level of Kamour oil pumping station. The region is home to the largest Tunisian hydrocarbon fields, as well as gypsum deposits, which does not protect it from having the highest unemployment rate in Tunisia $(28.2 \%) .{ }^{23}$ As for the third movement studied here, an expression of rural protest, it has specificities compared to the collective actions of young urban unemployed in the interior regions. It took place in Jemna, an oasis town of just over 7,000 inhabitants, located in the Kebili governorate in southwest Tunisia, $600 \mathrm{~km}$ from Tunis. It also embodies the will of the Jemna peasants to re-appropriate land considered despoiled by the State in the aftermath of independence, then monopolized by the region's rentier bourgeoisie. In doing so, the Jemna oasis has become a symbol of resistance to the State and an experiment in participatory self-management, a source of inspiration and promotion of the social and solidarity economy.

By examining the normative principles and objectives that guide these movements' action on the basis of their social and political experience, by analysing the diversity of their action repertoire, their organisation mode, their inscription in time and geography, the rules of

beyond the relevance of Gramscian concepts to describe a number of socio-political dynamics in post-Ben Ali Tunisia, Gramscian thinking, despite its non-dogmatic character, remains attached to the view of a socialism resting, in fine, on the 'ultimate ontological foundation' of the working class. Indeed, as Ernesto Laclau and Chantal Mouffe note: "there must always be, in any hegemonic formation, a unique unifying principle and it can only be a fundamental class", in this case the bourgeoisie or the working class. See Hégémonie et stratégie socialiste (Paris: Fayard/Pluriel, 2018), 133. Consequently, they should be handled with caution, which is what Patrizia Manduchi invites us to do in her introduction to the special issue of The Journal of North African Studies devoted to a Gramscian reading of revolutionary processes in North Africa: Patrizia Manduchi (2020), 'Between old and new epistemological paradigms: Gramscian readings of revolutionary processes in Egypt and Tunisia', The Journal of North African Studies, DOI: 10.1080/136293'87.2020.1801265

${ }^{21}$ That is to say the economic elite who draws their resources from their proximity to political power. See Aziz Krichen, La gauche et son grand récit. Comprendre l'économie rentière (Tunis, Nachaz, 2021).

${ }^{22}$ The region's unemployment rate in 2019 was $22 \%$ compared to $15.3 \%$ at the national level. The Kasserine governorate has the third highest poverty rate in Tunisia, 32.8\%. See INS, Carte de la pauvreté en Tunisie, octobre 2020 et INS, Indicateurs de l'emploi et $d u$ chômage. Deuxième trimestre 2019, Août 2019, http://www.ins.tn/sites/default/files/publication/pdf/Note_ENPE_2T2019_F2.pdf

${ }^{23}$ Ibid. 
decision-making in the struggle (the arts of governing protest), the aim is to show, beyond convergences and divergences, how their challenging the official political sphere is the expression of a desire for State action, a rejection of the State, a demand for socio-economic equality and, last but not least, an aspiration for more participatory democracy.

Before moving on to our demonstration, we would like to point out that we draw most of our empirical elements from press articles and recent works by young Tunisian sociologists published in Arabic by the Tunisian Forum for Economic and Social Rights (FTDES). In particular, we used two books that can be downloaded from the FTDES website, which bring together field surveys based on qualitative interviews with the main collective action ${ }^{24}$ activists together with data published by the media. More concretely, as far as the Kasserine protests are concerned, we have relied in particular on Ben Alia's ${ }^{25}$ study, while for Kamour we have used mainly Samira Hamdi's. ${ }^{26}$ As for our analysis of the of Jemna experience, it is based on the work by Ali Knis, ${ }^{27}$ Foued Ghorbali and Mounir Saidani ${ }^{28}$ as well as on Mohamed Rami Abdelmoula ${ }^{29}$ and Sami Bejj Okkez's ${ }^{30}$ journalistic investigations. Finally, we "boost" our case studies by adding other data, obtained in particular from press articles published by the Tunisian daily Le Maghreb.

\section{'We no longer want to be discriminated against in this way': between a desire for State action and rejection of the State}

Beyond their differences, whether through collective actions developed in regions with mineral and hydrocarbon wealth, or in an agricultural area such as Jemna, all the protest movements denounced the segregation of the hinterland and demanded jobs, 'development' and an economic and social rebalancing in favour of coastal regions; secondly, protests were structured around the same repertoire of action: to the classic sit-ins, sit-ins with camps were added, and coordinations were set up to make collective action more effective.

\footnotetext{
${ }^{24}$ Both books can be downloaded from the FTDES website at the following link: https://ftdes.net/ar/. The first, by Foued Ghorbali and Mounir Saïdani, al-Harakat al-Ijtmâ'iyya fî̀ Tûnis. al-siyâqât, al-fâ'ilûn, al Af'âl wa sînâriyûhât al tatawwur al muhtamala [Social movements in Tunisia: frameworks, actors, actions and conceivable scenarios]. Report of the FTDES, National Congress of Social Movements (undated), takes stock of the social movements that took place in Tunisia between 2011 and 2018. It documents case studies of the main social movements based on qualitative surveys using interviews conducted by the authors and the compilation of data published by the media. The second book, entitled Sûsîyûlûjiyâ al-fi'l al-Jamâ'î fî̀ Tûnis mundhu 14 Jânfî 2011 [Sociology of collective action in Tunisia since 14 January 2011], Les cahiers du FTDES, 2 (2019) offers several case studies concerning the Kasserine, Kamour and Jemna protest movements.

${ }^{25}$ Mouldi Ben Alia, 'Khusûsiyyat al-fi'l Jamâ‘î fî al-Hawâmish. Qira’a fî̀ Hudûd al-Haraka al-Ihtijâjiyya Jânfî 2016 [The specificities of collective action at the margins, reading the limits of the January 2016 protest movement]', in Sûsîyûlûjiyâ al-fi'l al-Jamâ‘î fî Tûnis mundhu 14 Jânfî 2011: 333-378

${ }^{26}$ Samiha Hamdi, "Itisâm al-Kâmûr bi-1-Janûb al-Tûnisî: Muwâtinûn 'adiyûn yujrihûn fî al-dîmuqrâtiyya alTamthîliyya [Kamour's sit-in in southern Tunisia: ordinary citizens create embarrassment in representative democracy]', in Sûsîyûlûjiyâ al-fi'l al-Jamâ‘î fî Tûnis mundhu 14 Jânfî 2011: 237-263 We have also relied on the chapter on Kamour in Foued Ghorbali and Mounir Saïdani, al-Harakat al-Ijtmâ'iyya fî Tûnis.

${ }^{27}$ Ali Knis, 'Jemna: al-Sirâ‘ hawla al-Ardh, al-Dawla fî Muwâjahat al-Mujtama' al-Mahalî [Jemna : the struggle for land, the state versus local society]', in Sûsîyûlûjiyâ al-fi'‘l al-Jamâ‘î fî Tûnis mundhu 14 Jânfî̀ 2011: 203-236. ${ }^{28}$ Foued Ghorbali and Mounir Saïdani, al-Harakat al-Ijtmâ‘iyya fî̀ Tûnis..

${ }^{29}$ Mohamed Rami Abdelmoula, 'Tajribet wahât Jemna fî̀ Tunis: amma ba'd... [The Jemma oasis experiment in Tunisia: and after...]' تجربة واحات جُمّنة في تونس: أما بعد.. | محمد رامي عبد المولى | السفير العربي (assafirarabi.com) ; 'alYasâr al-Tûnisî mâ "b'ad al-Thawra” Imtihân al-Harakât al-Ijtima“iyya [The post-revolution Tunisian left in the test of protest movements]' in Mohamed Rami Abdelmoula, Sofiane Jaballah, Foued Ghorbali, 'Arâjîn alGhadhab [The dates of anger], Tunis, Nachaz, 82-92.

${ }^{30}$ Mohamed Samih Beji Okkez, "tajribet Jemna : masîret qarn min ajli istirdâd al-ardh" [Jemna's experience: a one hundred-year journey to reclaim the land] al Muffakira al Qânûniyya, 17/11,2020,
} 
However, the movements in areas with natural resources have their own specificities. Their demands for regional equality are expressed mainly through one demand: being the first to benefit from their local resources ${ }^{31}$. Secondly, they have greater means of pressure on the central government than others insofar as they can block production sites that are vital to the country's economy.

The extension and transformation of the protests: from the Kasserine movement against privilege to the democratic coordinations by 'excluded and despoiled' Tunisia

Among the triggers sparking off these popular uprisings, events that undermine the demand for equality before the law hold an important place in the Tunisian context. This "register of equality claims" refers to "the denunciation of "pull' and preferential treatment" ${ }^{\text {". }}$. In terms of social movement theory, it refers to the framework of injustice ${ }^{33}$ and recalls the existence of a "moral shock" linked to the emotion aroused by an event that becomes the trigger for a protest mobilising old networks or sparking off new ones ${ }^{34}$. The January 2016 Kasserine uprising is an illustration of this. Its starting point was the death by electrocution of a young 28-year-old unemployed graduate, Ridha Yahyaoui. In 2015, he was part of a group of about thirty sit-in workers who signed an agreement with state representatives providing for their hiring. However, in the end, the administration crossed his name off the list of recruits and replaced him with another. On 16 January 2016, on the fringes of the demonstration organised against the modification of the hiring list, he climbed an electric pole and threatened to commit suicide. He then ended up electrocuted.

This act, interpreted by young lower-class people as the consequence of a form of contempt (hogra) displayed by authorities, led in the following two weeks to a series of uprisings that spread to two thirds of the country's governorates: demonstrations, sit-ins and other riots led to looting and the torching of several police stations. While riots ceased, the protest movement was gradually structured around sit-ins in the various regions. The sit-ins, these 'militants from the margins', which Mouldi Ben Alia ${ }^{35}$ studied during the Kasserine, Gafsa and Zaghouan governorates sit-ins, elected representatives who were entrusted by the collective to negotiate with authorities. They are mostly young men (28 to 32 years old), unemployed, university graduates $(90 \%)$ whose political consciousness 'was shaped by the revolution' ${ }^{36}$. The sit-ins delegates reframe (in the sense of the theory of frames, frame extension ${ }^{37}$ ) the demonstrations representations and watchwords, which go from denouncing 'pull' to demanding a job, and then to claiming regional development. These protesters' action repertoire is classic ${ }^{38}$ : sit-ins in front of administrations' headquarters, marches prior to demonstrations organised in front of governorates' headquarters, blocking of access roads to the region of Kasserine, blocking of the Ministry of Employment's street, hunger strike.

\footnotetext{
${ }^{31}$ Imed Melliti, 'Les inégalités comme injustices', in ed. Imed Melliti \& Hayet Moussa, 105

32 Ibid., 103.

${ }^{33}$ Robert D. Benford and David A. Snow, 'Framing processes and social movements: an overview and assessment', Annual Review of Sociology, 26 (2000): 611-639.

${ }^{34}$ James M. Jasper, The Art of Moral Protest. Culture, Biography and Creativity in Social Movements, Chicago (III.) University of Chicago Press.

${ }^{35}$ Mouldi Ben Alia, Khusûsiyyat al-fi'l Jamâ '̂̂ fì al-Hawâmish, 333-378.

${ }^{36}$ Hassen Ayadi, 'Thâhirat al-Tansîqiyât : al-Shajara allatî Tahjab al-Ghâb, [The phenomenon of coordination: see the wood for the trees]', Le Maghreb, 4/12/2020.

37 On the theory of frames applied to collective action in the Maghreb as a whole, see Frédéric Volpi, 'Le mouvement protestataire algérien de 2019 à la lumière de la théorie des mouvements sociaux et des printemps arabes', L'Année du Maghreb 21, no2 (2019): 27-36.

${ }^{38}$ For a general overview about the "repertoire" concept see Charles Tilly \& Sidney Tarrow, Contentious Politics (Boulder: Paradigm Publishers). For a description in the Tunisian case of Kasserine protests, see Ben Alia, Khusûsiyyat al-fi'l Jamâ '̂̀ fì al-Hawâmish, 357.
} 
Faced with demonstrators' desire to structure their collective action, the government deployed a diversified strategy combining the dismissal of a few administrative officials, the promise of development projects, the ad hoc recruitment and co-option of particular protesters groups ${ }^{39}$, the denunciation of the inconvenience caused by the blocking of roads and the destruction of property in order to discredit demonstrators.

In response to wait-and-see strategies, banking on popular collective actions' loss of momentum and breakdown, young activists from the margins have developed forms of organisation that are independent from political formations and trade union structures, thereby better able to sustain themselves over time, namely coordinations. These coordinations bring together activists who, as a rule, have elected a coordinator and a spokesperson who are accountable to their peers in sit-ins. They have various functions, including the occupation logistics, which often take the form of encampments and blockade of production and transport sites ${ }^{40}$. These forms of organisation are not new; the novelty lies in their generalisation and, therefore, in the appropriation by young unemployed people of an art of participatory and deliberative selfgovernment, characterised by a low level of hierarchy and concern for elected officials' control and accountability. These forms of organisation create mobilisation structures that tend to persist beyond each wave of protest. $^{41}$

These forms of horizontal mobilisation are poles apart from the way these populations understand the governance of these new elected bodies, political and trade union formations or State services. In so doing, coordinations' youths denounce the government, which leaves them no choice but to practice a survival economy (informal trade, smuggling, small trades...), a situation that, they say, results from hinterland populations being abandoned by the State. Consequently, they complain they are not part of the political community it embodies: 'nothing binds me to the State, except for my identity card', says one of the young people interviewed in Kasserine by sociologist Mouldi Ben Alia ${ }^{42}$ as well as the young unemployed Imed Melliti met. However, this statement should not be mistaken for a determination to secede, quite the contrary. It is the expression of the need for State action; a protective State that recognises inhabitants' citizenship, well beyond its political attributes, by providing them with a stable job and the material means to access an urban consumption mode that enables them to have a decent life. Here we find the unfulfilled promises of the developmentalist State dating from independence.

\section{Kamour: from pre-emptive rights over natural resources to learning about democracy}

The second type of protest movement we will analyse is emblematic of the mining and hydrocarbon production regions. The accounts of young people from segregated regions collected by Imed Melliti ${ }^{43}$ invoke the construction of an independent State monopolised by the Sahel and Tunis elites, who never ceased to despise them and to drain the interior governorates' wealth. In his survey, the Tunisian sociologist shows that young people claim that "their" wealth 'illegitimately benefits other regions, i.e., "foreigners" (el-barranya) to the detriment of the

\footnotetext{
${ }^{39}$ Irene Weipert-Fenner notes that, in the context of the unemployed graduates' movements the authorities co-opt "small groups with very specific demands, mostly employment for members of that specific group of protesters" in the context of a "divide-and-rule strategy that increases competition among different groups while also rewarding fragmented protests that shy away from broader demands or forms of organisations that could be considered "political": "Unemployed mobilisation in times of democratisation: the Union of Unemployed Graduates in post-Ben Ali Tunisia', The Journal of North African Studies 25, no1 (2020): 53-75.

${ }^{40}$ Ayadi, Thâhirat al-Tansîqiyât.

${ }^{41}$ Donatella della Porta, Where Did the Revolution Go? Contentious Politics and the Quality of Democracy (Cambridge: Cambridge University Press, 2016)

${ }^{42}$ Ben Alia, Khusûsiyyat al-fi'1 Jamâ‘î fî al-Hawâmish, 360.

${ }^{43}$ Melliti, Les inégalités comme injustices.
} 
country's children'. They therefore demand 'a pre-emption right over the regions' resources based on the autochthony principle" ${ }^{44}$. Kamour protesters' slogan 'Where is my right to natural wealth?' is the quintessence of this intention to pre-empt marginalised regions' wealth. This feeling of not benefiting from hydrocarbon revenues is further reinforced because these extractive industries are highly polluting and have not invested much in clean-up programmes to repair the damage they have caused to the environment. Moreover, the Kamour experience is paradigmatic of this model of self-organisation that coordination is, which will extend to other popular mobilisations. A quick description of collective actions around the Kamour oil zone will enable us to better understand the way in which sit-ins (mostly by young unemployed people aged between 20 and 35) have set up their coordination.

Kamour, which is about $120 \mathrm{~km}$ away from the city of Tataouine, is home to an oil-pumping station owned by Trapsa, a State-owned company whose mission is to transport Algerian and Tunisian crude oil by pipeline. In April 2017, the sit-ins that started to develop in Tataouine quickly showed their limit: they could not stop the trucks that were going to the Kamour pumping-station. So, on 23 April, the sit-ins, which had elected a coordination, decided to set up camp on the pumping-station site. Consisting of 81 tents, housing 15 to 20 people each, the sit-inners cut off the supply to the pipeline and decided to occupy the site until their demands were met $^{45}$.

In these difficult desert environment conditions, the coordination takes care of logistics, including the delivery of food and funding from local migrants living in Canada, and organises the rotation of the sit-in-campers so that they can rest at home at regular intervals. At an intermediate level between the coordination and the mass of sit-inners stand the 'tent leaders' who organise debates and voting in the camp on issues related to negotiations with the authorities and the actions to be taken ${ }^{46}$.

This conflict in Kamour, which was appeased for a moment following the signing of an agreement between the authorities and the sit-inners on 16 June 2017, resumed in 2018 due to the government's failure to fulfil its commitments.

In this regard, Kamour is a case in point of how authorities have handled protest movements since 2014. National or regional authorities sign agreements with the protesters' spokespersons, which are never upheld by public authorities. To quell the protests, authorities have adopted delaying tactics that consist of announcing measures and signing agreements that they have no intention of implementing, but which have the virtue of smothering protests for a while. However, grounds for anger endure, and the dormant mobilization networks are ready to kick in again when circumstances are right. ${ }^{47}$ Now these have become favorable again with the arrival of Kaïs Saïed to the presidency of the Republic in 2019. By his populist attitude, the new president has reignited the momentum of the movement. On December 17, 2019, after delivering a particularly offensive speech in Sidi Bouzid, i.e. on the day of the ninth anniversary of the outbreak of the revolutionary uprising, Kais Saied sent a letter of his chief of staff to the sit-in coordination members in Kamour. In it, the chief of staff was assuring them of the special attention he pays to the implementation of the agreement left pending. On January 15, 2020, he received the Kamour sit-in representatives. Containment measures have paralyzed for a time the sit-in participants' aspirations. The decline of the first covid-19 wave at the end of spring

\footnotetext{
44 Ibid.

${ }^{45}$ Samiha Hamdi, Itisâm al-Kâmûr bi-l-Janûb al-Tûnisî, 237-263.

${ }^{46}$ Ibid. 252.

47 Choukri Hmed, 'Abeyance networks, contingency and structures. History and origins of the Tunisian revolution', RFSP 62, 5-6 (2012): 797-820.
} 
and the end of the lockdown allow the Kamour sit-in coordination representatives (namely its spokesman Tarek Haddad and its general coordinator Dhaou el Ghoul) to relaunch the protest. ${ }^{48}$ Faced with the reemergence of the movement, pro-government media were called upon to try to disqualify the Kamour sit-in by describing a 'campaign with regionalist connotations', denouncing the sit-in as "a group of outlaws, the self-proclaimed representatives of the Tataouine inhabitants" 49 , and stating that the government should not negotiate with the "bandit' of Kamour". ${ }^{50}$ Other editorialists lamented the weakness of the State and regretted that the public authorities had not reacted, for fear that "the Soros-paid human rights activists and other international donors will accuse them of attacking the freedoms to demonstrate and to express themselves". 51

The ruling party has also alternately played the repression game - by arresting the two main sitin figures (Dhaw el Ghoul, its coordinator; and Tarek Haddab, its spokesman, for common law violations) - and periods of negotiation with a delegation composed of national organizations' local representatives (the Tunisian General Labor Union, the Tunisian Union of Industry, Commerce and Handicrafts, etc.), lawyers, accountants, and associations in the region.

The sit-in reached its peak between July and early November 2020 with a new blockade of the pumping-station organised by the coordination, and then ended (albeit perhaps only temporarily) with the signing of a second agreement between sit-in representatives and authorities. In doing so, it spread throughout November and December 2020, in "why not us?" mode. A similar wave of protests reached other regions, with sit-ins organised by coordinations, mainly in the hydrocarbon production and distribution sector.

Like in Kamour, the Douleb coordinations sit-inners (occupation of an oil pumping-station in the Kasserine governorate) or Samoud 2 (blocking gas cylinders filling units in the Gabes industrial zone), called for implementing various measures relating to the regions' economic, cultural and health development previously adopted by the Chahed government's Councils of Ministers (August 2016-February 2020). ${ }^{52}$

Demonstrators' demands in both Kasserine and Kamour are rooted in a demand for equality, social justice and wealth redistribution. In the young protesters' narrative, the unjust State must repair the original exclusion by providing its victims with permanent jobs in the public sector. In doing so, protesters are inscribing themselves, in renewed forms, in the clientelist functioning of resources distribution dear to Bourguiba and Ben Ali's authoritarian regimes. Since 2011, the rulers' authoritarian practices have been scaled down, 'but the clauses of an implicit contract that glosses over the wealth creation issue in favour of paternalistic redistribution remain ${ }^{53}$. In other words, the demands expressed by the sit-in coordinations are

\footnotetext{
${ }^{48}$ Manel Derbali, 'Itisâm Kamour, al-Sallam al-Zamani, Mâres 2017-nûfember 2021' [Chronology of the Kamour sit-in, march 2017-november 2017], Nawaat, 27/11/2020 Nawaat - اعتصام الكامور: السلّم الزمني [مارس 2017 - نوفمبر $[2020$

${ }^{49}$ Mounir Chebil, 'Le mouvement El-Kamour signe la faillite de l'Etat tunisien', Kapitalis, 8 décembre 2020, http://kapitalis.com/tunisie/2020/12/08/le-mouvement-el-kamour-signe-la-faillite-de-letat-tunisien/.

${ }^{50}$ The online newspaper, Kapitalis, describes Tarek Haddad, the spokesman for the Kamour sit-in, as an "arrogant and disrespectful' man who believes he can impose his will on a weakened Tunisian state [...], which all the scum of the country can now trample underfoot". See 'Photo of the day: the State negotiates with a highwayman, cap on backwards, 8/10/2020, http://kapitalis.com/tunisie/2020/10/08/photo-du-jour-letat-negocie-avec-un-bandit-desgrands-chemins-casquette-a-lenvers/

51 Amel Bel Hadj Ali, 'Tunisie: il faut casser le mythe du surdiplômé sous-qualifié', Webmanagercenter, 21/09/2020, https://www.webmanagercenter.com/2020/09/21/456085/tunisie-il-faut-casser-le-mythe-dessurdiplomes-sous-qualifies/

52 Seif Soudani, 'Tunisie : les raisons d'un climat pré-insurrectionnel', Le Courrier de l'Atlas, 30/11/2020, https://www.lecourrierdelatlas.com/tunisie-les-raisons-dun-climat-pre-insurrectionnel/

${ }^{53}$ Michaël Ayari and Thierry Brésillon, 'Le retour du parti Ennahda sur la scène politique : de la normalisation démocratique au compromis autoritaire?', in Tunisie au présent: une démocratisation au-dessus de tout soupçon, ed. Amin Allal and Vincent Geisser (Paris: CNRS Editions, 2018), 99.
} 
an expression of the need for a tutelary State whose logic persists, through a hysteresis effect, in post-Ben Ali Tunisia.

\section{Rent sharing and the need for State action}

Since 2011, the government has responded to phosphate and hydrocarbon producing regions' demands for jobs and development, with varying degrees of grace, by resorting to external debt and a delaying tactic to buy time. ${ }^{54}$ In other words, it tried to buy social peace in order to avoid, as far as possible, the production disruption or stoppage. To do this, authorities first ask national or foreign mining companies to hire unemployed people. Then they recruit young people on fictitious jobs through public worksites and horticulture, environment and gardening companies (SHEJ). ${ }^{55}$

The grievances programme developed by the Kamour sit-in coordination in 2017 followed the same rent-sharing logic that fuelled another protest episode in the Kerkennah Islands a year earlier: ${ }^{56}$ it demanded the hiring of 3,000 young people in the local SHEJ, the creation of 1,500 jobs in the oil companies and the allocation of 100 million Tunisian dinars per year to a regional development fund. The 16 June 2017 agreement signed between the coordination and the Tunisian government ratified most of these demands ${ }^{57}$.

This rentier logic also fuelled a clientelist socio-economic dynamic with part of the local private sector. ${ }^{58}$.

This need for State action expressed by protesters in mineral and hydrocarbon producing areas is rather alien to the rural world. Admittedly, the domination mechanisms of the city over the countryside have gone through different forms of marginalisation. To summarise the Tunisian small peasantry's situation, it can be said that since independence, it has been the victim of the government's resolve to create a large agricultural domain controlled by the state and to impose

54 On "waiting as a mode of government in Tunisia", see Hamza Meddeb, 'L'attente comme mode de gouvernement en Tunisie', in L'État d'injustice au Maghreb. Maroc et Tunisie, ed. Irene Bono et al. (Paris: Karthala, 2015), 345-377.

${ }^{55}$ Hassen Ayadi, 'Hukûmat al-Fakhfâkh wa Ikhtibâr al-Kâmûr: al-Khiyâr satattajihu ilayh? Shirâ' al-Salâm alIjtimâ‘î am al-Islâh? [The government and the Kamour experience: which option will it choose? Buy social peace or reform?]', Le Maghreb, 23/06/2020.

${ }^{56}$ In the case of the sit-in protests in the Kerkennah Islands, it is the determination of the British gas company, Petrofac, and the Tunisian government to renege on the agreements made with the protesters after the 2010-2011 uprising that triggered the reactivation of the movement. In 2011, and again in 2012, the said agreements provide for Petrofac to contribute 1 million Tunisian dinars per year to a fund intended to cover the salaries of 266 unemployed graduates in different administrations. However, following the publication of a report by the Court of Auditors denouncing the fictitious nature of $70 \%$ of the jobs financed this way, the company asked the government to participate in the financing of the fund. The Tunisian leaders failed to respond, and the company stopped contributing to the fund, which led to a wave of sit-ins that resulted in the blocking of gas extraction in 2016. See Foued Ghorbali and Mounir Saïdani, al-Harakat al-Ijtmâ 'iyya fî Tûnis : 151.

${ }^{57}$ Éric Gobe, 'La Tunisie en 2017: impotence de l'État et tentations autoritaires', L'Année du Maghreb 19, no2 (2018): 235-256.

${ }^{58}$ In the case of the Gafsa mining basin, this rationale has fueled the functioning of the rentier-mafia system, established under Ben Ali. In 2012, young unemployed people occupied the Gafsa Phosphate Company (CPG) sites throughout the year and prevented the loading of ore onto Société nationale des chemins de fer tunisiens trains (SNCFT). These initiatives have enabled the Company of Product Transport (STTPM) created the same year, to secure, along with three other transport companies, authorization from the CPG to transport the ore at rates 3 to 5 times higher than SNCFT prices. This gave rise to a new jobs category, the Bayacha, i.e., workers paid by road transport companies to cover the trucks once the ore had been loaded into the skips. Samiha Hamdi, Jeunes et action politique: Comportement électoral et nouvelles formes d'expression dans l'espace urbain en Tunisie, doctoral dissertation, sociology/architecture specialization (Grenoble: Université Grenoble Alpes, 2018), 211. 
a low price-policy on food-producing agriculture in order to support both overemployment in the public sector and a low wages policy. ${ }^{59}$

\section{Land dispossession and rejection of the tutelary State: Jemna's self-management experience}

The December 2010-January 2011 popular uprising also concerned central Tunisia's rural regions and was often led by landless peasants and agricultural workers ${ }^{60}$. In particular, it challenged the State's land policy implemented by the independent Tunisia's first governments. To understand this phenomenon and its emblematic experience - the Jemna oasis palm grove example - it is necessary to go back to 1964 and the nationalisation of land held by French settlers. Instead of returning or redistributing them to the peasants, the government entrusted them to an Office des terres domaniales placed under administration supervision. ${ }^{61}$ Imbued with a 'modernising', 'socialising' and paternalistic ideologies, it was unthinkable for the independent state's elites that Tunisian peasants, considered backward and imbued with tribal values, could profitably exploit the agricultural domains that had been despoiled by the coloniser. Once the socialist parenthesis was closed in 1969, the independent State's management of state-owned land mostly left a chronic deficit and resulted, under Ben Ali's presidency, in a system of widespread corruption ${ }^{62}$ : in order to relieve the State's budget, rulers rented out the land for derisory rents to investors close to the deposed president.

\section{From land occupation to self-management}

This form of continuous land-grabbing since colonisation has remained in some peasant communities' collective memories, which were just waiting for a spark to be rekindled ${ }^{63}$ It was precisely the revolutionary moment that sparked off the revival: 'in several regions, farms were attacked and occupied, crops confiscated". ${ }^{64}$ However, this reappropriation of land was perpetuated in the Jemna palm grove alone, which became a successful symbol of the 'revolution of dignity'.

In Jemna, the State allocated the nationalised domain's management to a State-owned company, the STIL (Société tunisienne des industries laitières), which was responsible for exploiting the palm grove and selling the local dates production. In the 2000s, under Ben Ali, following the bankruptcy of STIL, the authorities decided to rent the farm to two developers close to the Trabelsi family, the in-laws of the deposed president. ${ }^{65}$

On 12 January 2011, in a theatrical gesture, dozens of young Jemnians occupied and seized the farm $^{66}$. The oasis inhabitants accused the two tenants of being corrupt and of cashing in on their close ties with the former regime to obtain the right to exploit the land by paying a paltry rent. The latter appealed to the army, which in the end, in the context of the revolutionary moment,

\footnotetext{
${ }^{59}$ Krichen, L'Autre chemin.

${ }^{60}$ Alia Gana, "Protestations et action collective en milieu agricole et rural. Enjeux et paradoxes du processus de changement politique en Tunisie", in Tunisie au présent: une démocratisation au-dessus de tout soupçon (ed.) Amin Allal and Vincent Geisser (Paris : CNRS Editions, 2018), 57-72.

${ }^{61}$ Mohamed Elloumi, 'Les terres domaniales en Tunisie. Histoire d'une appropriation par les pouvoirs publics', Études rurales n¹92 (2013) : 43-60.

${ }^{62}$ Krichen, L'Autre chemin, 103.

${ }^{63}$ More specifically, with regard to land owned in undivided ownership by local tribal groups.

${ }^{64}$ Elloumi, 'Les terres domaniales en Tunisie', 43-60.

${ }^{65}$ Henda Chennaoui, 'The STIL farm in Jemna: when collective interest overrides personal gain', Nawaat, 11/07/2015, https://nawaat.org/2015/07/11/la-ferme-de-la-stil-a-jemna-quand-linteret-collectif-devance-le-gainpersonnel/

${ }^{66}$ Mohamed Kerrou, 'L'Oasis de Jemna entre les modes de fonctionnement bureaucratique et les logiques de l'émancipation civile', in Révolutions et émancipations ed. Mohamed Nachi (Tunis: Nirvana, 2017), 146-164.
} 
did not intervene, while hundreds of the oasis inhabitants organised a sit-in in front of the farm that lasted 96 days ${ }^{67}$. From this sit-in and the popular meetings that took place in Ras el Aïn central public square in Jemna, the local committee for the protection of the revolution emerged and organised itself to self-manage the estate. ${ }^{68}$

In early 2012, the local committee was dissolved and replaced by the Jemna Oasis Protection Association (Association de protection des oasis). Seven of the ten members of its board of directors were activists with trade union and political backgrounds and from diverse activist ideologies (left-wing, Arab nationalism and Islamism). Professionally, they belonged to the middle-class from the civil service (managers and pensioners). Alongside them sat small farmers with an elementary school education. ${ }^{69}$ In addition, Taher Tahéri's personality emerged from this council. He was a country child, a pioneer of trade union action in the education sector in Kebili, the neighbouring town. His long militant experience gave him regional social capital and he embodied a 'charismatic resistance' ${ }^{70} \mathrm{He}$ was the architect of the breakaway line that was imposed on the government's determination to return to the status quo ante after 2014. His role is also a reminder that peasant societies, in the absence of 'natural' representatives (the landowning notables), were used to resorting to personalities from the terroir to assume the role of interlocutor with the public authorities established in the provincial or national capital-city. These intermediaries, who came from the local community, generally for professional reasons, had to distinguish themselves by their mastery of the communication codes and relays of the global society they had joined, ${ }^{71}$ while maintaining an equal relationship with the peasant community (i.e., by developing practices, periodically challenged, that comply with respect and attention standards towards their constituents). ${ }^{72}$

The Association's governing body oversaw the operation of the farm. Its members acted voluntarily, receiving neither a salary nor a percentage of the profits. They reported at regular intervals to the Jemna population gathered in Ras el Ain square. ${ }^{73}$ This experiment in associative land management was an undeniable economic success, as evidenced by an increase in yields and agricultural workers' income. In addition, part of the profits is used to finance development projects for the benefit of the Jemna municipality. ${ }^{74}$

\section{State law as a symbol of the dispossession of the peasantry}

Although public authorities consider the association's action to be illegal, they chose to turn a blind eye to this social and economic experiment for five years. However, they were not ready to make the association's activity legal for fear that Jemna's example might "pave the way for a multiplication of claims around state farms, risking in the long run the liquidation of the state's

\footnotetext{
${ }^{67}$ Ghorbali and Saïdani, al-Harakat al-Ijtmâ 'iyya fî Tûnis.151.

${ }^{68}$ The majority of Jemnians supported the indivisibility of the land and wanted it to be preserved and exploited collectively, while a minority suggested that it be shared among the inhabitants. See Mohamed Rami Abdelmoula, 'al-Yasâr al-Tûnisî mâ "b 'ad al-Thawra”, 82-92.

${ }^{69}$ Ali Knis, Jemna: al-Sirâ' hawla al-Ardh, al-Dawla fî Muwâjahat al-Mujtama ' al-Mahalî, 203-236.

${ }^{70}$ Jean-Claude Monod, Qu'est-ce qu'un chef en démocratie? Politique du charisme (Paris : Seuil, Points essais, 2012).

${ }^{71}$ Henri Mendras, Les sociétés paysannes (Paris: Gallimard, 1995).

${ }^{72}$ Pierre Rosanvallon, The Society of Equals, (Cambridge: Harvard University Press, 2013).

${ }^{73}$ It submits an external audit report to them every year by a chartered accountant.

${ }^{74}$ Mohamed Samih Beji Okkez, “Jemna's experiment: a one hundred-year journey to reclaim the land , 17/11,2020, Legal Agenda (legal-agenda.com). The year 2014 was the first time the Jemna experiment successes actually kicked in. According to Mr. S. B. Okkez, who consulted the external audit reports of the Jemna Oasis Protection Association, the revenues from date exploitation increased sharply, stabilizing at an average of DT 1.6 million until the fall of 2019. After deducting expenses and workers' salaries (whose number increased from 40 in 2011 to 152 permanent workers in 2019), these revenues were used for of the region's economic, social and cultural development.
} 
agricultural domain"75. The arrival in office of part of the former regime's elite in the wake of the 2014 presidential and legislative elections encouraged them to put an end to this experiment, which was all the more damaging to the 'prestige of the state' (haybet al dawla) as the latter was blamed by Jemnians for its inability to make the management of its state-owned land profitable. At the end of October, they recalled that the domain was State property and took the matter to court to get the auction of the year's harvest to be cancelled.

In doing so, by fighting the Jemna experiment, they were helping to raise its profile. The Association reacted on social networks by communicating the legitimacy of its actions and the Jemna community's claims. Under the impetus of Taher Tahéri, the association's politicised and unionised members mobilised, both locally and nationally, the associative networks, as well as the political parties likely to support the socio-economic experiment. On 9 October, ignoring the injunction from public authorities, the Association organised an auction of the date harvest, which was won by a wholesale trader from the region ${ }^{76}$. Journalists, activists from associations and social networks as well as parliamentarians from the opposition were present that day, while parliamentarians from the Popular Front and the Democratic Current intervened in Parliament and in the audio-visual media to defend the Association and its action ${ }^{77}$.

The State estate administration countered by issuing an order to seize the date harvest, freezing the Association's bank account and the funds of the trader who had bought the 2016 crop, and taking legal action to cancel the auction of the year's crop. The government also relied on its own media to denounce the illegality of the Association's practices and to disqualify Taher Tahéri as an outlaw ${ }^{78}$.

\section{"Off the ground" resistance: the campaign in support of Jemna switching from local to national}

Resistance to the government's coercive policy was also taking place in Tunis. In late September, early October 2016, the idea of organising a support group from the capital emerged. A little less than a hundred former activists from left-wing political parties, activists from the associative sector, and residents from Jemna who had settled in the capital met to launch a campaign in support of the Jemna experience. They were middle-class university students and civil servants. ${ }^{79}$

The newly formed collective's members created a Facebook community and decided to organise a caravan in support of the Association and the village of Jemna (on the model of the 1 and 2 sit-ins in Kasbah) to attend the date harvest auction. Members left Tunis and went to the palm grove on 8 and 9 October. On their return, the collective's activists, who wanted to broaden and sustain their movement, officially dubbed their group the 'national campaign to support Jemna', and chose a motto and a hashtag for the campaign: 'Free Jemna! General interest before private profit'. ${ }^{80}$

Until the end of 2017, when a modus vivendi was found between the Association and public authorities, the collective's mobilisations borrowed from a repertoire of protest actions against the government and from classic media or direct public awareness-raising modes of action (sitins, petitions, press conferences, information seminars, contradictory debates and date distribution). ${ }^{81}$

\footnotetext{
${ }^{75}$ Gana, Protestations et action collective en milieu agricole et rural. 66.

${ }^{76}$ Ghorbali and Saïdani, al-Harakat al-Ijtmâ 'iyya fî Tûnis.

${ }^{77}$ Abdelmoula, al-Yasâr al-Tûnisî mâ "b 'ad al-Thawra”, 85.

${ }^{78}$ Ghorbali and Saïdani, al-Harakat al-Ijtmâ 'iyya fî Tûnis.

${ }^{79}$ Knis, Jemna: al-Sirâ ' hawla al-Ardh, 220.

${ }^{80}$ Ibid., 218.

${ }^{81}$ Ibid., 219.
} 
In fact, as of the end of 2016, the government played the appeasement game: it withdrew the monitoring of the case from the State's domains and handed it over to the Ministry of Agriculture. Throughout 2017, the Ministry of Agriculture negotiated the terms of an agreement with the Association and Jemnians, which initially met with reservations because the State was to remain the owner of the land. The Ministry proposed to the Association to upgrade into an agricultural development company to which the State would lease the estate. The Jemnians finally accepted the Ministry's offer, which would provide them with long-term tenure of the former collective land. ${ }^{82}$

From the point of view of the forms taken by collective action, Jemna's "agro-rural" experience of is no less interesting. By reconstructing the sequence of events around the Jemna experience, we were able to understand how collective action and its audience were structured over six years; how it developed forms of social resistance intended to react to the public authorities' initiatives by mobilising the local historical memory of a despoliation; how the Association's mobilisation entrepreneurs, notably its president, assumed the role of mediator between local and global society; then how they were able to widen their audience to mobilise activists as well as political and associative personalities living in Tunis; and, finally, how the government's strategy of disqualifying the movement did not succeed in discrediting the Jemnians' action.

The governmentality crisis was built around the rural world's experience of how unfair the original colonial dispossession was, as much as its post-independence perpetuation by paternalistic elites. The response to this feeling of dispossession took the form of occupying both the land and Ras el Aïn's central square. Jemnians reappropriated both the public space, the square transformed into an Agora where speaking out became possible and audible, as well as a heritage land, a means of family economic reproduction, left by the State in the hands of a political-business mafia. However, while the palm grove's inhabitants and the Association's managers succeeded in asserting their conviction and their desire to share the wealth produced, undoubtedly, the Jemna self-management experiment did not spread.

Ultimately, it was the national political and associative actors who grafted themselves onto Jemna's collective action, which was not knowledgeable enough, unable or unwilling to amplify the 'frame' of the movement ${ }^{83}$ and transform it into a 'deterritorialised' cause, i.e. a public problem likely to be taken on by public policy or measures with a national scope. There was never any question of agrarian reform to change the status of State-owned land.

The experience did, however, provide an opportunity to transcend territorial scales for Tunis middle-class youth, who, in tandem with Jemnians in the capital, organised a support campaign. In doing so, they participated in a form of mobilisation (the campaign) that reached its peak between 2016 and 2019, thereby enabling a sector of politicised urban youth that had been turned off by political parties, to mobilise against government action by experimenting with a democracy made up of self-organised collectives. ${ }^{84}$

\section{Conclusion}

The coordinations' demands, which have developed in recent years, are rooted in a demand for equality, social justice and redistribution of wealth. In the narrative of the young protesters from the mineral and hydrocarbon rich regions, the unjust State must compensate for their original exclusion by providing them with permanent jobs in the public sector. In doing so, protesters are framing themselves, in renewed forms, in the clientelist functioning of resources distribution by Bourguiba's and Ben Ali's authoritarian regimes. In this context, the young protesters from

\footnotetext{
${ }^{82}$ Mohamed Rami Abdelmoula, 'Tajribet wahât Jemna fî Tunis: amma ba‘d...'

${ }^{83}$ Benford and Snow, Framing processes and social movements.

${ }^{84}$ (anonymized, authors of the paper)
} 
the interior have an ambivalent relationship with the State: that institution is hated as being confiscated by an elite alien to their region (Tunisian and Sahelian), which allegedly diverts its abundant wealth at their expense. At the same time, the State is perceived as a "cash box". The objective is then for protesters to recover a share of the "booty" appropriated by those in power, who will distribute resources only if pressure is put on them. Thus, the Kamour agreement would perpetuate the predation and rent cultures that challenge the principle of equality among Tunisian citizens. As for the mobilizations around the Jemna experience, they have brought together social solidarity economy advocates, who believe in its ability to boost the development of agricultural regions. They aspire to generalizing the transformation of state farms and collective lands into production and service cooperatives. Now the Jemna experience appears to be an isolate inserted in traditional market mechanisms. Moreover, State-owned land remains the main issue in disputes in various governorates. In particular, the government has refused to give in to the demands of unemployed graduates in the Meknassi region (Sidi Bouzid governorate) who were asking for the right to acquire and exploit part of the land, which is State property. This official stance is due to the fear of the affirmation of a supposed 'socialist model' that contradicts the neoliberal option promoted in the framework of the Comprehensive and Deep Free Trade Agreement (CFTA) being negotiated between Tunisia and the European Union. State-owned land is thus meant to be sold to national and international investors with a view to industrialize agriculture in line with the market economy logic. ${ }^{85}$

The crisis of Tunisian governmentality is not limited to the case studies presented in this article. It refers to other phenomena and events expressing the desire of large sections of Tunisian society "not to be governed like this". Not the least of these events is the recent proclamation of a state of emergency on July 25, 2020 by the President of the Republic, Kais Saïed, based on an "extensive" reading of Article 80 of the Constitution. This presidential 'coup de force' is, in our view, a further symptom of the multiple facets of the Tunisian governmentality crisis. The popular demonstrations, to approve the decision to freeze the work of parliament and lift its MPs' immunity, reflect a massive rejection of the parliamentary order instituted by the $2014^{86}$ Constitution and the sharing of power - of its privileges and rents - between the Islamoconservative movement leaders of Ennahdha and part of the elites of the old regime present in the Nidaa Tounes party and its avatars. It remains to be seen whether President Said's desire to "correct the revolution" - i.e., to establish a political regime that articulates forms of direct democracy and a powerful President of the Republic who asserts himself as the "mouth of the people" - is capable of establishing a new form of governmentality that would resolve the hiatus between the representatives and the represented while putting an end to the operating logic of the rentier system.

\footnotetext{
${ }^{85}$ Fouad Ghorbali, 'Tûnis: al-Dawla wa Arâdhîha al-mu'ammama [Tunisia: The state and its nationalised land]', al-Safir al-Arabi, 18/04/2019.

${ }^{86}$ See in this regard the opinion survey on the decisions taken by the President of the Republic conducted by EMRHOD consulting: $87 \%$ of respondents agree (fairly favorable and very favorable) with the measures taken by Kais Said. Note that the decisions the population is most enthusiastic about were the lifting of of MPs' parliamentary immunity ( $83 \%$ are very favorable) and the freezing of the activity of Parliament $(81 \%$ are very favorable). 178242572212927/photos/pcb.4113406825363129/4113403172030161
} 